\title{
PENGOBATAN TRADISIONAL SEBUAH KAJIAN INTERAKSIONISME SIMBOLIK
}

\author{
Hendri Setiawan \\ hendrisetiawanbu@gmail.com \\ IKIP Budi Utomo Malang \\ Jalan Citandui 46 Malang \\ Faizal Kurniawan \\ faizalkurniamsi@gmail.com \\ IKIP Budi Utomo Malang \\ Jalan Citandui 46 Malang
}

\begin{abstract}
People have a belief in finding different healing from one another. Some people entrusted to medical treatments, and the others entrusted to traditional treatments. Those who did traditional treatments believe that because of their culture which forms the society's behavior to entrust healing through traditional treatment. For the people of Desa Tutut Arjowinangun Malang, Pengobatan tradisional is a socio-cultural treatment or treatment based on culture. Pengobatan Tradisional here uses a dream interpretation that can only be done by the healer or shaman Pengobatan Tradisional. The solution of the pain suffered by the patient is derived from a dukun's dream interpretation and combined with the ritual of giving salt to the patient. The ability of healers, shamans, or healers to carry out traditional medical practices is not obtained by chance or by accident, but by a certain stage or ritual. A healer or dukun has the ability to carry out his traditional treatment practices also through the possession of heirlooms. They are like kris and or ancient weapons in the past, stone, jewelry, and so on. These heritage objects are believed to give a power to perform a ritual both for treatment and other activities that can not be done by most humans. In addition to some of the explanations that have been outlined above, traditional medicine still has a place in the Society due to the support of the surrounding community. The village community of Tutut Arjowinangun gives trust to the dukun Pengobatan Tradisional to provide an alternative for healing. The community of Desa Tutut Arjowinangun Malang has different perception about illness. The majority of Tutut Arjowinangun Malang Village people interprete medical illness as a disturbance of the body's metabolic system. But the people of Desa Tutut Arjowinangun Malang who still adhere to cultural values will certainly have different perception on the pain. As Foster points out that a personalistic system is a system in which illness is caused by the intervention of an active agent, an active agent here being a supernatural being. These supernatural beings are like supernatural beings or gods, non-human beings such as ghosts, ancestral spirits or evil spirits as well as human beings in the form of sorcerers or sorcerers. So here the sick person is the victim, the object of aggression or punishment specifically directed to him for special reasons concerning him alone.
\end{abstract}

Keywords: Traditional Medicine, Heart Belief Model.

Masyarakat Indonesia mempunyai keanekaragaman budaya yang begitu kaya. Budaya tersebut melekat erat dalam kehidupan masyarakatnya. Menurut Soerjono (1990;72) masyarakat yang hidup bersama maka akan menghasilkan kebudayaan. Dengan demikian, tidak ada masyarakat yang tidak memiliki kebudayaan dan begitu pula sebaliknya, tidak ada kebudayaan tanpa masyarakat yang membentuknya. Salah satu contoh dalam hal pengobatan, masyarakat di Indonesia masih percaya kepada pengobatan yang bersifat kultural atau pengobatan kebudayaan. Pengobatan kultural atau biasa disebut pengobatan tradisional ini bersifat turun-temurun dari nenek moyang sampai kepada anak cucu. Pengobatan tradisional ini menjadi sebuah budaya karena adanya keyakinan dalam diri masyarakat di Indonesia, bahwa pengobatan tradisional dapat menyembuhkan apa yang tidak bisa disembuhkan oleh pengobatan yang bersifat medik. Selain itu adanya sebuah kesepakatan sosial bahwa pengobatan tradisional adalah sesuatu metode yang cocok untuk diterapkan dalam suatu kalangan tertentu.

Pada model kepercayaan masyarakat Desa Tutut Arjowinangun dalam mencari kesembuhan, masyarakat Desa sebagian besar 
mempercayakan pencarian kesembuhannya melalui cara medis seperti melalui dokter, bidan atau petugas kesehatan lainnya. Akan tetapi ada sebagian masyarakat desa ini yang masih mempercayakan kesembuhannya pada pengobatan yang bersifat sosio-kultural atau pengobatan tradisional. Pengobatan ini telah dipercaya masyarakat sejak jaman dahulu, dikarenakan pada jaman dahulu di desa ini masih sangat jarang terjamah oleh pengobatan yang bersifat medis. Selain alasan tersebut, masyarakat Desa Tutut Arjowinangun masih menggunakan cara tradisional dalam mempercayakan kesembuhannya dikarenakan ada beberapa penyakit yang tidak bisa disembuhkan melalui cara medis. Salah satu contoh kasus adalah penyakit step atau kejang yang diderita oleh anak anak yang dapat disembuhkan melalui metode pengobatan tradisional. Biasanya dengan cara sawan kejang pada anak dapat disembuhkan.

Salah satu contoh pengobatan tradisional yang akan dibahas dalam penelitian ini adalah Pengobatan Tradisional. Di Indonesia, metode Pengobatan Tradisional ini sebenarnya telah lama dikenal masyarakat yang masih mempercayakan kesembuhannya pada pengobatan tradisional. Selain itu adanya kepercayaan masyarakat Indonesia yang menganggap bahwa penyakit yang datangnya dari alam ghaib diluar alam sadar manusia, maka penyakit tersebut hanya mampu disembuhkan melalui metode yang bersifat majik. Metode ini telah dikenal sejak lama oleh masyarakat Desa Tutut Arjowinangun sebagai metode penyembuhan untuk beberapa penyakit tertentu. Metode ini merupakan metode pengobatan sosio-kultural dengan salah satu orang tabib (healer) dimana tabib itu memberikan jawaban kesembuhan melalui mimpi. Jadi mimpi dari seorang tabib itu adalah kunci dari akar permasalahan penyakit yang dibawa oleh orang sakit tersebut.

Masyarakat Desa Tutut Arjowinangun masih mempercayakan pada sistem pengobatan tradisional yang mengedepankan proses supranatural. Pengobatan yang sistem ini biasanya dilakukan oleh dukun ataupun orang yang dipercaya atau diyakini masyarakat untuk melakukan pengobatan terhadap suatu macam penyakit. Nilai budaya atau cultural value systems dan mengenai sikap atau attidude itu mempengaruhi munculnya pola-pola cara berpikir yang akan mempengaruhi tindakan (Sajoyo; 1988) baik itu dalam kehidupan seharihari atau dalam mengambil sebuah keputusan.

Seseorang mencari kesembuhan terhadap gejala atau penyakit dilakukan dengan cara yang berbeda-beda. Hal ini dikarenakan apa yang ada dalam pemikiran ataupun keyakinan individu tersebut berbeda. Faktor-faktor sosial dan kultural mempengaruhi pemahaman individu terhadap penyakit dan penyebaran melalui pengaruh mereka dalam hubungan antara beberapa populasi manusia dan lingkungan alamnya. Atau melalui pengaruh langsung pada kesehatan sebuah populasi. Dalam pemahaman Lieban, kesehatan dan penyakit adalah pengukuran efektivitas dengan dimana kelompok manusia menggabungkan sumber daya kultural dan biologikal, menyesuaikan dengan lingkungan mereka.

Adanya perbedaan dalam pengambilan keputusan baik secara modern dengan sistem medis seperti apa yang telah dilakukan oleh petugas kesehatan seperti dokter, farmasi, atau pengobatan lain, dengan cara non medis seperti sosio kultural atau sebuah kepercayaan melalui pengobatan supranatural. Kedua macam pengobatan baik itu secara modern ataupun pengobatan tradisonal yang bisa juga disebut pengobatan sosio-kultural (missfortunes) dalam memberikan suatu kesembuhan terhadap penyakit dalam struktur kehidupan sosial masyarakat di Indonesia tidak bisa dipisahkan antara satu sama lain. Dapat dikatakan pengguna pengobatan yang bersifat pengetahuan secara biologis atau pengobatan medis itu adalah orangorang yang berfikir secara positivis atau pencarian apa yang diyakini itu bergantung dari apa yang dilihat dan dapat dibuktikan ulang lagi dalam percobaan laboratorium.

Individu mengambil keputusan dalam berobat dengan metode medis karena dia tahu akan kebenaran ilmu pengetahuan sebagaimana yang telah dipelajari dalam dunia kedokteran dan kesehatan dapat dipercaya menyembuhkan penyakit. Sedangkan bagi mereka yang percaya bahwa fakta-fakta yang terjadi di dalam masyarakat bahwa pengobatan missfortunes adalah pengobatan yang dapat menyembuhkan penyakit, maka mereka akan berobat ke dukun.Pengobatan dalam jenis ini biasanya menggunakan majik yang secara medis tidak 
pernah dibahas, akan tetapi secara sosio-kultural pengobatan dengan cara seperti ini dapat menyebabkan kesembuhan bagi penyakit yang diderita. Suatu contoh kasus, konsep sakit atau Illness diyakini dalam dunia medis adalah sebagai gangguan dari metabolism organ-organ tubuh sehingga menyebabkan gangguan dalam suatu sistem organ. Akan tetapi dalam pengobatan supranatural konsep Illness ini diyakini sebagai suatu gangguan dari alam lain diluar alam sadar manusia sebagai gangguan, cobaan atau hukuman yang diterima individu akibat adanya kekuatan diluar alam sadar manusia.

Disini kita melihat bahwa konsep kesehatan di Indonesia tidak hanya dari segi medis saja, akan tetapi metode tradisional juga mendapatkan tempat di hati masyarakat Indonesia sebagai salah satu keyakinan untuk menyembuhkan suatu penyakit. Tidak hanya metode Pengobatan Tradisional yang dapat dilakukan untuk memberikan kesembuhan bagi penderita akan tetapi banyak pengobatan tradisional lain yang diyakini masyarakat sebagai salah satu metode untuk menyembuhkan. Penelitian ini merumuskan masalah yang akan diteliti secara mendalam dengan mengaitkan teori yang sesuai dengan keadaan yang ditemukan dilapangan. Adapun rumusan masalah dari penelitian ini adalah apa makna pengobatan Pengobatan Tradisional bagi Masyarakat Desa Tutut Arjowinangun Malang

\section{METODE}

Penelitian ini menggunakan pendekatan kualitatif dan menggunakan pendekatan studi kasus untuk mendapatkan gambaran dari hasil penelitian. Metode penelitian dicari dengan tepat untuk dapatnya digunakan sebagai metode dalam penelitian ini. Penelitian ini tergolong penelitian deskriptif kualitatif karena salah satu alasannya bahwa penelitian ini tidak bisa dilepaskan dari konteksnya. Langkah pertama yang dilakukan dalam penelitian ini adalah mengobservasi tempat penelitian adalah dengan observasi. Usaha pengamatan atau observasi yang cermat, dapat dianggap merupakan salah satu cara penelitian ilmiah yang paling sesuai bagi para ilmuan dalam bidang ilmu sosial (Harsja : 1990).

\section{HASIL DAN PEMBAHASAN Konsep Sehat Sakit}

Kesehatan merupakan konsep holistik yang mencakup aspek-aspek fisik, mental, dan sosial. Pengetahuan dan pemahaman tentang kesehatan sangat dibutuhkan untuk berperilaku sehat, kebiasaan yang dilakukan berdasarkan pemahaman yang baik. Untuk mencapai derajat kesehatan diperlukan pondasi yang kuat dan benar tentang pengetahuan kesehatan (Etjang 1999;58). Secara ilmiah penyakit atau yang disebut dengan disease itu diartikan sebagai gangguan fungsi fisiologis dari suatu organisme sebagai akibat dari infeksi ataupun tekanan dari lingkungan. Sedangkan sakit atau illness adalah penilaian individu terhadap pengalaman menderita suatu penyakit. Perilaku sakit diartikan sebagai segala bentuk tindakan yang dilakukan oleh individu yang sedang sakit agar supaya individu tersebut mendapatkan pengobatan.

Dari segi medis, penyakit merupakan invasi organisme mikro, infestasi parasite atau serangan masuknya substansi kimia atau fisik (Benyamin 1987;15). Seorang petani miskin di desa, ataupun seorang direktur perusahaan besar di kota, akan membayangkan suatu malapetaka yang menimpa dirinya bila dikemukakan kepadanya keadaan yang disebut penyakit. Sebagian orang merasakan bahwa penyakit sulit didefinisikan. Demikian banyak jenis ganguan yang dapat menyebabkan orang jatuh sakit, maka pendefinisian penyakit sebaiknya juga mengurai berbagai jenis gangguan tersebut. Pada umumnya pihak awam melukiskan penyakit sebagai sesuatu yang tidak beres berkaitan dengan alat tubuh atau jiwa seseorang.

Dari penjelasan diatas dapat disimpulkan bahwa penyakit bukan hanya penyimpangan biologis organ atau berbagai organ tubuh yang disebabkan oleh peristiwa biologis dalam alam sekitar manusia, tapi juga penyimpangan mental dan sosial seseorang yang disebabkan oleh berbagai faktor psikologis dan sosiologis. Kesehatan dan penyakit merupakan ukuran betapa efektifnya manusia dapat menyesuaikan diri terhadap lingkungannya dengan memanfaatkan sumber biologis dan sumber budayanya. Pemanfaatan sumber biologis merupakan bidang kedokteran, sedangkan pemanfaatan sumber budaya merupakan bidang sosiologi dan antropologi budaya.

Pada mulanya penyebab penyakit secara ilmiah selalu dikaitkan dengan pengetahuan 
tentang anatomi dan fisiologi tubuh manusia dan tentang biologi faktor penyebabnya. Namun kemudian ternyata bahwa tidak lah mungkin menjelaskan penyebab penyakit semata-mata sebagai satu atau beberapa faktor biologis. Perilaku manusia, lingkungan abiotis dan berbagai pengaruh fisik, sosial dan budaya senantiasa bekerja sama, atau saling mempengaruhi, sehingga bersama penyebab biologis, akhirnya timbullah penyakit itu pada manusia.

Masyarakat yang masih mengedepankan

medis dalam kepercayaan mencari kesembuhannya tentu akan berbeda mengartikan sakit dengan masyarakat yang msih mengedepankan proses pengobatan budaya atau tradisional. Masyarakat yang masih mengedepankan medis tentu akan menganggap penyakit sebagai gangguan dari metabolisme anatomi tubuh. Lain halnya dengan masyarakat yang masih mempercayakan kesembuhannya kepada pengobatan yang bersifat kultur atau tradisional mungkin menganggap penyakit sebagai hukuman dari sang pencipta ataupun adanya gangguan dari makhluk halus.

Seorang ahli sosiologi dan psikologi sosial Mechanic dalam Solita, mengembangkan teori tentang perilaku sakit yang dinamakan olehnya teori respon bertahan. Menurutnya perilaku sakit adalah reaksi optimal dari individu jika individu tersebut terkena penyakit. Dan reaksi ini sangat ditentukan oleh sistem sosialnya. Perilaku sakit erat hubungannya dengan konsep diri, penghayatan situasi yang dihadapi. Menurutnya (Solita 2004;39), ada dua faktor utama yang menentukan perilaku sakit yaitu yang pertama adalah persepsi atau difinisi individu tentang situasi atau penyakit. Kemudian yang kedua adalah kemampuan individu untuk melawan serangan penyakit tersebut. Perilaku sakit ini juga diteropong oleh Suchman yang memberikan batasan perilaku sakit sebagai tindakan untuk menghilangkan rasa tidak enak atau rasa sakit sebagai timbulnya gejala tertentu. Suchman menganalisa pola proses pencarian pengobatan dari segi individu dan petugas kesehatan. Menurutnya ada lima macam reaksi dalam proses pencarian pengobatan antara lain 1. Shopping, yaitu mencari alternatif sumber pengobatan guna menemukan seorang yang dapat memberikan diagnosa pengobatan sesuai dengan pengobatan. 2. Fragmentation, yaitu proses pengobatan oleh beberapa fasilitas kesehatan pada lokasi yang sama. 3. Procrastination, yaitu proses penundaaan pencarian pengobatan, meskipun gejala penyakitnya sudah dirasakan. 4 . Self Medication, yaitu pengobatan sendiri, dengan menggunakan berbagai macam ramuan atau obat-obatan yang dinilai tepat baginya. Kemudian yang terakhir adalah 5. Discontinuity, atau penghentian proses pengobatan.

\section{Health Belief Model dalam Pengambilan Keputusan}

Rosenstock dalam Solita (2004;66), mengatakan bahwa perilaku individu ditentukan oleh motif dan kepercayaannya, tanpa memperdulikan apakah motif dan kepercayaan tersebut sesuai atau tidak sesuai dengan realitas atau cara pandang orang lain tentang apa yang baik untuk individu tersebut. Sangatlah penting untuk membedakan antara kebutuhan kesehatan yang obyektif dan subyektif. Kebutuhan kesehatan yang obyektif ialah yang diidentifikasi oleh petugas kesehatan berdasarkan penilainnya secara professional, yaitu adanya gejala yang dapat mengganggu atau membahayakan kesehatan individu. Sebaliknya individu menentukan sendiri apakah dirinya menderita suatu penyakit, berdasarkan perasaan dan penilaiannya sendiri. Model kepercayaan Rosentock kesehatan ini mencakup lima unsur utama. Yang pertama adalah persepsi individu tentang kemungkinannya terkena suatu penyakit (perceived susceptibility). Mereka yang merasa dapat terkena penyakit tersebut akan lebih cepat merasa terancam. Unsur yang kedua adalah pandangan individu tentang beratnya penyakit tersebut (perceived seriousness), yaitu resiko dan kesulitan apa saja yang akan dialaminya dari penyakit itu. Makin berat resiko suatu penyakit, dan makin besar kemungkinannya bahwa individu itu terserang penyakit tersebut, maka akan besar ancaman yang akan diterimanya (Per-ceived threats). Ancaman ini mendorong individu untuk melakukan tindakan pencegahan atau penyembuhan penyakit. Apabila ada konsekuensi negatif dari solusi yang ditawarkan oleh individu yang memberikan pendapat seperti biaya yang mahal, rasa malu, takut akan rasa sakit maka hal ini akan menyebabkan individu akan 
menolah sebuah metode atau cara pengobatan tersebut (Perceived benefits and barriers) .

Disini persepsi-persepsi individual berbeda masing-masing individu menandakan bahwa setiap individu memiliki keputusan yang menurut keyakinannnya diyakini sesuai. Setiap usia, jenis kelamin, etnik suku bangsa, dan kepribadian, serta status sosial ekonomi, serta tingkat pengetahuan masing-masing individu dalam merasakan ancaman dari penyakit. Jadi seseorang yang mempunyai status ekonomi tinggi dan status ekonomi rendah mempunyai keyakinan dalam mencari kesembuhan yang berbeda. Selain itu etnik juga mempengaruhi keyakinan individu dalam mencari kesembuhan. Misal dalam suatu komunitas suku bangsa, pengobatan tradisional biasa digunakan masyarakat tersebut. Jadi dapat disimpulkan bahwa di daerah tersebut pengobatan tradisional itulah yang digunakan.

Selain itu dari bagan diatas dapat dilihat bahwa pendidikan dan gejala-gejala juga dapat mempengaruhi keputusan seseorang dalam menentukan kemana ia akan mengambil kepercayaan untuk kesembuhannya. Peran media disini juga sangat mempengaruhi seseorang dalam mengambil keputusan untuk berobat. Kita tau bahwa peran media elektronik dalam mempengaruhi perilaku seseorang sangat besar. Bisa jadi, dalam perilaku berobat seseorang dipengaruhi media elektronik.

\section{Pengobatan Tradisional dalam Masyarakat}

Menurut surat keputusan menteri kesehatan nomor 1076/MENKES/SK/VII/2003 pengobatan tradisional adalah pengobatan dan atau perawatan dengan cara, obat dan pengobatannya yang mengacu kepada pengalaman, keterampilan turun temurun, dan atau pendidikan dan pelatihan, dan ditetapkan sesuai norma yang berlaku di dalam masyarakat.

Menurut Mangan (2003;30) cara pengobatan yang ada di kalangan masyarakat sekarang bisa disimpulkan kepada dua tipe pengobatan yaitu pengobatan cara barat yang bersifat konvensional dan juga dianggap modern serta pengobatan cara timur yang bersifat alternatif atau seringkali disebut pengobatan tradisional. Secaraa umum pengobatan timur bertujuan untuk meningkatkan sistem imun, menghambat pertumbuhan penyakit, mengurangi keluhan pengguna dan memperbaiki fungsi badan tubuh. Berbeda dengan pengobatan barat dimana membuang kangker dengan pembedahan, membunuh sel kanker dengan kemoterapi ataupun radioterapi untuk sel yang invasive. Paradigma yang diterapkan dalam pengobatan barat adalah "illness is the enemy" sedangkan pengobatan timur menyebutnya paradigma "llness is not an enemy but caused unbalanced energy" menyebabkan perbedaan cara pandang masyarakat serta aplikasi keduanya pada upaya pelayanan kesehatan pada masyarakat.

Pengobatan tradisional oleh dukun merupakan tahapan-tahapan subjektif yang tidak dapat diukur. Hal tersebut tidak memiliki variable yang jelas, dengan demikian ahli kesehatan lain tidak dapat mengukur kebenaran maupun kesalahan metode yang digunakan. Dukun pengobat memiliki wewenang kharismatik, yaitu kemampuan atau wibawa ini dimiliki tanpa dipelajari, tetapi ada dengan sendirinya (Anggorodi : 2009)

\section{Penyakit, Religi, dan Magi}

Pengobatan, religi, dan magi sedimikian seringnya didiskusikan, seakan-akan ketiganya adalah bagian yang sangat penting dari suatu sistem sehingga sering kali menanyakan kapankah ketiganya tidak berjalan seiring. Namun apabila dihubungkan angtara religi, magi, dan etiologi, tampak jelas bahwa kedua belah pihak berkorelasi dengan sistem-sitem naturalistik. Dalam sistem naturalistik, prosedur pengobatan jarang bersifat ritual, dan unsur-unsur religi dan magi sedikit sekali berperan di dalamnya (Foster 1986;64).

Ada beberapa daerah di Indonesia menggunakan pengobatan tradisional dengan cara yang religius seperti datang ke kyai atau pemuka agama. Pemuka agama tersebut membacakan doa khusus kemudian memberikan air kepada penderita sakit agar diberikan kesembuhan oleh yang maha kuasa. Dalam perspektif pengobatan modern hal ini biasa disebut dengan sugesti, karena dalam pengobatan modern dengan datang ke orang yang dipercayaai dapat menyembuhkan penyakit itu sudah merupakan sugesti kepada si sakit untuk optimis dalam kesembuhannya. 
Pengobatan tradisional Pengobatan Tradisional termasuk dalam kategori pengobatan yang berlandaskan unsur magis. Hal ini dapat dilihat dari epidemologi penyakit dari Pengobatan Tradisional selalu dikaitkan dengan hal-hal yang bersifat magis. Seseorang yang sakit selalu diartikan bahwa sakit tersebut disebabkan oleh gangguan makhluk supranatural yang hanya dapat dilihat oleh orang tertentu yang biasa disebut dukun, tabib (healer). Begitu pula kemampuan untuk mengobati penyakit hanya dapat dilakukan oleh orang tertentu yang memiliki benda pusaka atau telah melakukan suatu tahapan untuk seseorang dapat mencapai suatu tujuan. Metode penyembuhan Pengobatan Tradisional didapat dari sebuah tafsir mimpi seorang dukun yang nantinya akan ditemukan penawar atau solusi bagi penyakit tersebut.

\section{Kultural Mistisisme Kejawen dalam Pengobatan Tradisional}

Masyarakat di Indonesia khususnya di pulau Jawa, dalam mengambil suatu tindakan ataupun berperilaku, masih terpengaruh oleh kebudayaan disekitar mereka. Terutama pada interaksi mereka sehari-hari, dari segi bahasa yang mereka gunakan, masyarakat Jawa tentu menggunakan bahasa Jawa dalam interaksi mereka sehari-hari. Pengaruh kebudayaan Jawa sangat melekat dalam kehidupan masyarakatnya, sehingga dari segi agamapun tidak lepas dari kebudayaan Jawa. Jawa adalah kelompok suku atau etnik terbesar di Asia tenggara. Etnik jawa berjumlah kurang lebih $40 \%$ dari 200.000.000 penduduk Indonesia. (Niels 2001;1)

Tradisi jawa adalah tradisi yang amat kaya dan dihimpun dari kesusasteraan yang merentang, paling kurang, selama seribu tahun mulai dari sumber-sumber kuno Sansekerta hingga kisah-kisah babad dan legenda kerajaan kuno. Tradisi jawa yang sering disebut juga Kejawen yang dalam bahasa Indonesia berarti "Kejawaan" atau Jawanisme. Kata terakhir ini menjadi sebutan deskriptif bagi elemen-elemen kebudayaan jawa yang dianggap Jawa secara hakiki dan hal itu didefinisikan sebagai suatu kategori unik. Elemen-elemen itu umumnya diduga berasal dari periode Hindu-Budha dalam sejarah Jawa, yang kemudian menyatu dalam sebuah filsafat dalam pengertian sebuah sistem tertentu mengenai prinsip-prinsip bertindak dalam kehidupan.

\section{Interaksionalisme Simbolik Dalam Pengambilan Cara Berobat}

Interaksionisme simbolik merupakan cabang kedua dari Behaviorisme Sosial. Interaksionisme simbolik bercirikan sikap (attitude) dalam arti (Meaning). Dalam aliran imitasi sugesti titik beratnya adalah masalah gejala atau fenomena. Interaksionisme simbolik berorientasi pada diri atau pribadi. (Wardi 2006;34) Charles Horton Coley berpendapat bahwa imajinasi yang ada dalam benak orangorang terhadap yang lainnya, menurut Cooley, adalah "Fakta di dalam Masyarakat". Masyarakat adalah sebuah fenomena mental, hubungan antar gagasan orang. "Masyarakat ada di dalam pikiranku seperti hubungan dan pengaruh timbal balik dalam gagasan tertentu yang diberi nama "aku". Masyarakat dan individu bukanlah dua realitas yang berdiri terpisah, akan tetapi dua sisi atau segi dari realitas yang satu dan sama. Keduanya adalah bagaikan dua sisi mata uang yang tidak dapat dipisahkan. Jadi disini masyarakat desa tutut arjowinangun berperan sebagai self jadi fakta-fakta yang terkuak di dalam Cara Pengobatan Tradisional ini berdasarkan fakta yang ada bahwa Cara

Pengobatan Tradisional ini mampu menyembuhkan bayi yang sedang sakit.

Bagi Blumer interaksionisme simbolis bertumpu pada tiga premis (1) manusia bertindak terhadap sesuatu berdasarkan makna-makna yang ada pada sesuatu itu bagi mereka; (2) Makna tersebut berasal dari "Interaksi Sosial seseorang dengan orang lain"; (3) Makna tersebut disempurnakan disaat proses interaksi sosial berlangsung.

Tindakan tersebut saling dikaitkan dan disesuaikan oleh anggota-anggota kelompok, hal ini disebut sebagai tindakan bersama yang dibatasi sebagai "organisasi sosial dari perilaku tindakan berbagai manusia.

Ada tiga teori yang termasuk ke dalam paradigma definisi sosial ini ${ }^{1}$, yakni : Teori aksi (action theory), teori interaksionisme simbolik (symbolic interactionism) dan teori fenomenologi (fhenomenology). Ketiga teori ini mempunyai kesamaan ide dasarnya yang berpandangan bahwa manusia adalah aktor yang aktif dan 
kreatif dari realitas sosialnya. Artinya tindakan manusia tidak sepenuhnya ditentukan normanorma, kebiasaan-kebiasaan, nilai-nilai dan sebagainya yang kesemuanya itu tercakup dalam fakta sosial. Manusia mempunyai cukup banyak kebebasan untuk bertindak di luar batas kontrol dari fakta sosial.

\section{Pengobatan tradisional di Desa Tutut Arjowinangun Malang}

Desa Tutut Arjowinangun Malang adalah sebuah desa di sebelah selatan Kota Malang, tepatnya di perbatasan antara Kota dan Kabupaten Malang. Desa ini berjumlah penduduk sekitar 300 orang. Desa ini mempunyai 12 Rukun Tetangga (RT) dan 7 Rukun Warga (RW). Letak geografis Desa Tutut Arjowinangun ini digambarkan dalam penjelasan berikut. Sebelah barat, Desa Tutut Arjowinangun berbatasan dengan Kecamatan Gadang, disebelah timur desa ini berbatasan dengan Desa, kemudian di sebelah utara, desa ini berbatasan dengan kecamatan Kedung Kandang, lalu di sebelah selatan desa ini berbatasan langsung dengan kecamatan Bululawang.

Bagi masyarakat Desa Tutut Arjowinangun Malang, Pengobatan Tradisional merupakan salah satu pengobatan yang bersifat sosio kultural atau pengobatan dengan dasar kebudayaan. Kebudayaan setiap kelompok masyarakat tersebut berbeda-beda antara satu sama lain. Seperti yang telah dijelaskan Foster (1986;147) dalam bab sebelumnya pengobatan dengan para penyembuhnya tersebut selalu berhubungan dengan berbagai tipe-tipe masyarakat, serta penyakit yang berbeda beda dalam suatu masyarakat tertentu. Pernyataan Foster inilah yang menjadi acuan dalam penelitian bahwa konsep pengobatan tradisional dari satu daerah dan daerah lain tersebut berbeda.

Kemampuan bagi healer, dukun, atau tabib yang melaksanakan praktik pengobatan tradisional tersebut tidak didapatkan secara kebetulan atau ketidak-sengajaan, melainkan melalui sebuah tahapan atau ritual tertentu. Dalam contoh pengobatan tradisional Pengobatan Tradisional Pada Masyarakat Desa Tutut Arjowinangun Malang, Seorang Dukun Pengobatan Tradisional Bernama Pi'i Memiliki
Kemampuan Untuk Melaksanakan Pengobatan Tradisional Pengobatan Tradisional Melalui Sebuah Warisan Dari Kedua Orang Tuanya Yang Pada Waktu Sebelumnya Sudah Dapat Melaksanakan Ritual Pengobatan Tradisional Tersebut, Sedangkan Istri Pi'i Yang Mempunyai Kemampuan Ipen Untuk Mengetahui permasalahan seseorang sehingga mendapatkan penyakit juga melalui suatu saat dimana dia diwariskan oleh seseorang yang mampu melakukan itu sebelumnya.

Seorang tabib atau healer memiliki kemampuan untuk melaksanakan praktik pengobatan tradisionalnya juga melalui kepemilikan benda-benda pusaka. Benda tersebut seperti keris dan atau senjata-senjata kuno pada masa lampau, batu, perhiasan, dan lain sebagainya. Benda-benda pusaka tersebut diyakini dapat memberikan sebuah kekuatan untuk melakukan suatu ritual baik untuk pengobatan maupun kegiatan lain yang tidak dapat dilakukan oleh manusia kebanyakan. Sebagaimana yang telah dikatakan oleh Mudler $(2001 ; 41)$ bahwa upaya tradisional meraih kekuasaan, kekebalan, dan potensi magis, menuju praktik-praktik yang lebih berorientasi psikologis dan spiritual. Jadi kepemilikan benda-benda pusaka tersebut menjadi salah satu penyebab seseorang dapat melakukan praktik mistisisme. Pada dasarnya, praktik mistisisme adalah upaya individual (Mudler 2001;41). Praktik mistisisme merupakan pencarian tunggal seorang manusia yang menghendaki penyatuan kembali dengan asalnya, yang mencita-citakan pengalaman penyikapan rahasia keberadaan, atau pelepasan dari segala ikatan duniawi.

Selain beberapa penjelasan yang telah dibabarkan diatas, pengobatan tradisional masih mendapat tempat di Masyarakat dikarenakan dukungan dari masyarakat sekitarnya. Masyarakat Desa Tutut Arjowinangun memberikan kepercayaan kepada Pi'i untuk memberikan alternatif bagi kesembuhannya. Jadi atas dasar kepercayaan masyarakat inilah Pi'i dapat terus menjalankan praktik pengobatan tradisionalnya. Kepercayaan masyarakat inilah yang menjadikan Pengobatan Tradisional Tetap digunakan masyarakat dalam mencari kesembuhannya.

Selain sakit dikaitkan dengan adanya kekuatan supranatural, masyarakat Desa Tutut 
Arjowinangun Malang memandang bahwa salah satu penyebab dari sakit adalah sebagai bentuk hukuman dari alam jika dia melanggar atau tidak sejalan dengan kondisi sosial yang seharusnya. Seperti yang dijelaskan oleh WHO bahwa sehat adalah suatu bentuk keseimbangan antara fisik jasmani, psikologis, dan kehidupan sosial seorang individu. Pada bab sebelumnya telah dijelaskan dalam kegiatan wawancara kepada pasien Pi'i yang menceritakan dia memiliki kesalahan dengan bertengkar kepada salah satu anggota keluarganya. Bertengkar disini adalah sebagai bentuk ketidak-sinambungan dalam suatu kondisi sosial sehingga seorang yang menderita sakit harus menerima sakit sebagai bentuk hukuman yang harus diterima. Jika seseorang ingin terbebas dari sakitnya, maka seseorang tersebut harus melakukan sebuah sacrifice atau sebuah kegiatan ritual yang harus dijalani sebagai tombo (penawar) bagi kesembuhan sakitnya.

\section{Masyarakat Desa Tutut Arjowinangun} juga membedakan konsep sakit dan pengobatan yang berbasis pada pengobatan yang bersifat Majik ini juga senada apa yang telah disampaikan (Frazer dalam Doni Saputra:2012) yaitu menjelaskan batas perbedaan antara religi dan ilmu ghaib "Ilmu ghaib adalah segala sistem, tingkah laku dan sikap manusia untuk mencapai suatu maksud dengan menguasai dan mempergunakan kekuatan-kekuatan dan kaidah-kaidah ghaib yang ada di dalam alam. Sebaliknya religi adalah segala sistem tingkahlaku manusia untuk mencapai suatu maksud dengan cara menyadarkan diri kepada kemauan dan kekuasaan makhluk-makhluk halus seperti rohroh makhluk halus yang menempati alam.

Jadi temuan pada penelitian ini adalah pada masyarakat yang masih memegang teguh nilai-nilai tradisional memandang sakit mempunyai dua penyebab yaitu pertama sakit itu disebabkan oleh adanya intervensi dari kekuatan supranatural yang disini adalah makhluk ghaib, maupun dari interpersonal dari tukang sihir (seperti contoh di Indonesia adalah santet) maupun benda-benda yang dikeramatkan seperti keris, kalung, dan lain sebagainya. Kedua, sakit tersebut dipandang sebagai gangguan pada suatu keadaan normal sosial individu, berparadigma bahwa sakit sebagai bentuk hukuman dari alam atas kesalahan yang diperbuat. Seseorang yang menyimpang, maka dia akan mendapatkan sakit sebagai bentuk hukuman.

Tidak ada keterkaitan antara tingkat pendidikan seseorang dalam mengambil keputusan untuk berobat pada pengobatan Tradisional Pengobatan Tradisional Ini. Terlihat Dalam Pasien Pi'i Yang Menggunakan Metode Pengobatan Tradisional Ini Sebagai Metode Pengobatan Primer Bagi Dirinya Adalah Dari Golongan orang yang mengenyam pendidikan cukup tinggi. Bagi mereka kepercayaan mencari kesembuhan adalah melalui pengalaman dari orang sebelumnya yang telah berhasil sembuh melalui satu jenis pengobatan tertentu. Bagi mereka tidak ada suatu paradigma tentang tingginya tingkat pendidikan untuk menentukan kemana dia akan mengambil metode kepercayaan mencari kesembuhan. Jadi disini masyarakat yang semula tidak meyakini akan dikotomi-dikotomi tentang dunia mistis, akan menjadi lebih memilih menggunakan metode tradisional yang masih sangat kental akan mistis seperti pada pengobatan Pengobatan Tradisional.

Selain temuan bahwa tidak ada pengaruh antara tingkat pendidikan dengan kepercayaan seseorang dalam mencari kesembuhan, maka dalam penelitian ini juga menemukan bahwa perbedaan keyakinan dalam memeluk suatu agama tertentu tidak mempengaruhi dalam keputusan dalam mencari kesembuhan. Dapat dilihat dari pasien Pi'i yang bukan hanya dari satu agama yang dianut dalam masyarakat mayoritas saja, akan tetapi seseorang yang menganut agama selain islam juga mempercayakan kesembuhannya kepada metode pengobatan tradisional.

Selain itu legitimasi Masyarakat Desa Tutut Arjowinangun Malang terhadap keberadaan praktek pengobatan Tradisional Pengobatan Tradisional Membuat Pengobatan Tradisional Pengobatan Tradisional Tersebut masih diterima dan masih tetap dipercaya oleh masyarakat sebagai salah satu bentuk kepercayaan dalam mencari kesembuhan. Hal tersebut adalah bentuk dari legitimasi tradisional dimana seberapa jauh masyarakat mau menerima kewenangan atau keputusan, atau kebijaksanaan yang telah dibuat oleh seorang tokoh dalam suatu komunitas masyarakat. Dapat disimpulkann melalui bagan 3.1 berikut ini 


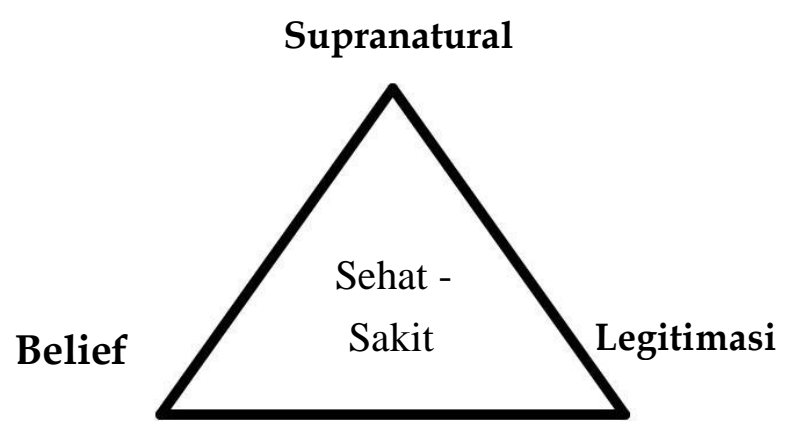

\section{Bagan 3.1 Bagan Komponen Kepercayaan Pencarian Kesembuhan}

Penjelasan pada bagan diatas adalah bahwa masyarakat desa tutut arjowinangun malang percaya bahwa sakit adalah adanya intervensi dari kekuatan supranatural yang mengganggu manusia. Mereka mempercayai bahwa yang dapat menyembuhkan hal-hal yang diakibatkan oleh kekuatan supranatural adalah orang yang mempunyai kemampuan untuk melintas alam supranatural. Untuk itu masyarakat memberikan legitimasi kepada Pi'i yang disini merupakan dukun PENGOBATAN TRADISIONAL untuk melakukan praktik pengobatan tradisional tersebut. Jadi legitimasi masyarakat disini adalah sebagai bentuk dukungan kepada praktik pengobatan tradisional PENGOBATAN TRADISIONAL yang dilakukan oleh Pi'i. Masyarakat percaya kesembuhannya dapat dilakukan melalui pengobatan yang sudah dilakukan secara turun temurun.

\section{KESIMPULAN}

Pengobatan tradisional berbeda penatalaksanaannya antara satu daerah dengan daerah yang lain. Hal ini dikarenakan keanekaragaman kultur budaya dan kebiasaan masyarakat dalam suatu daerah. Pengobatan tradisional tetap dipercaya sebagai salah satu kepercayaan pencarian kesembuhan dikarenakan tradisi turun temurun pada suatu

komunitas masyarakat. Tidak ada pendidikan formal untuk mempelajari suatu pengobatan yang bersifat tradisional, karena pengobatan tradisional muncul akibat adanya suatu kebiasaan yang terjadi di kelompok masyarakat. Kadang masyarakat memberikan sebuah "kesepakatan" kepada seseorang yang diyakini dan dipercaya dapat melakukan suatu praktik pengobatan.
PENGOBATAN TRADISIONAL adalah salah satu bentuk pengobatan tradisional di Desa Tutut Arjowinangun Malang. Bagi masyarakat

Desa Tutut Arjowinangun Malang, PENGOBATAN TRADISIONAL adalah suatu pengobatan kepada balita yang sistem pengobatannya tidak menggunakan obat seperti yang dipelajari dalam ilmu farmakologi. Masyarakat Desa Tutut Arjowinangun Malang membuat suatu kesepakatan kepada orang yang bernama Pi'i untuk melakukan praktik pengobatan tradisional PENGOBATAN TRADISIONAL. Kesepakatan yang diberikan masyarakat kepadanya dibuat menjadi sebuah tradisi turun temurun dari keluarga Pi'i untuk mewariskan kemampuannya untuk melakukan praktik pengobatan tradisional PENGOBATAN TRADISIONAL.

Masyarakat Desa Tutut Arjowinangun Malang masih tetap menggunakan metode pengobatan tradisional karena beberapa alasan diantaranya, adanya anggapan dengan menggonakan sistem pengobatan medis maka mereka akan mengeluarkan banyak biaya untuk membeli obat ataupun dalam perawatannya. Selain itu masyarakat Desa Tutut Arjowinangun Malang beranggapan bahwa ada suatu penyakit yang disebabkan oleh adanya kekuatan supranatural diatas alam pikir manusia biasa. Penyakit yang disebabkan oleh kekuatan supranatural atau majik hanya bisa diobati oleh kekuatan supranatural juga. Masyarakat Desa Tutut Arjowinangun Malang juga masih mempercayakan kesembuhannya pada pengobatan tradisional juga sebagai bentuk pelestarian budaya, karena bagi masyarakat Desa Tutut Arjowinangun Malang, budaya adalah suatu pedoman dalam menjalani kehidupan sehari-hari.

Dalam pembahasan kajian pustaka pada bab sebelumnya dijelaskan bahwa penyakit tidak hanya disebabkan gangguan dari sistem metabolisme tubuh dan fisiologis manusia saja, akan tetapi kehidupan sosial dan sistem missfortunes atau kepercayaan bahwa ada penyakit yang disebabkan oleh kekuatan supranatural. Untuk itu kita memandang penyakit itu tidak hanya dari segi medis saja, akan tetapi dari segi sosial budaya juga perlu diperhatikan bagaimana mengartikan penyakit tersebut. 
Selain itu, bagi pemerintah hendaknya memberikan fasilitas berupa perijinan secara resmi bagi seseorang yang membuka pengobatan tradisional. Dan dengan didukung oleh program penyuluhan kesehatan bagi masyarakat sehingga masyarakat dapat menilai mana mitos dalam masyrakat yang tidak mendukung dalam hal kesehatan masyarakat dan mana yang mendukung kesehatan masyarakat.

\section{DAFTAR RUJUKAN}

Anggorodi, R, 2009, “Dukun Bayi Dalam Persalinan Oleh Masyarakat Indonesia", Makara Kesehatan, Vol 13, no 1, Juni, PP 9-14

Entjang, E. 1999 Pendidikan Kesehatan Sekolah, Bandung: Cipta. Bandung

Foster, Anderson. 1986 Antropologi Pendidikan, , UI Press, Jakarta
Lumenta, B. 1987 "Penyakit, Citra, Alam, dan Budaya", Kanisius, Yogyakarta

Mulder, N. 2001, "Mistisisme Jawa, Ideologi di Indonesia", LKIS, Yogyakarta

Wardi, B. 2006 "Sosiologi Klasik", PT Remaja Rosdakarya, Bandung,

Sajoyo \& Pudjiwati, S. 1988 "Sosiologi Pedesaan"

Gajah Mada University Press, Yogyakarta

Saputra, D. 2012 “Sistem Pengobatan tradisional pada Masyarakat, Nagari Sikucur, Kecamatan V, Koto Kampung Dalam Kabupaten Padang"

Skripsi, Universitas Andalas

Sarwomo, S. 2004 "Sosiologi Kesehatan" Gadjah

Mada University Press, Yogyakarta

Suchman dalam David S Gochman, Health

Behavior, New York, Plenium Publishing Corporation

Soekanto, S. 1990 "Sosiologi, Suatu Pengantar" PT Raja Grafindo, Jakarta 